\title{
The importance of being petioled: leaf traits and resource-use strategies in Nuphar lutea
}

\author{
Alice Dalla Vecchia ${ }^{\mathbb{D}} \cdot$ Rossano Bolpagni
}

Received: 27 April 2021 / Revised: 13 December 2021 / Accepted: 20 January 2022 / Published online: 4 February 2022

(C) The Author(s) 2022

\begin{abstract}
Intraspecific trait variability (ITV) can be considerably high and reveal plant local adaptation. The aim of this study is to investigate ITV of leaf traits (including petioles) in a rooted floating-leaved macrophyte (Nuphar lutea) at the local scale. We expected to see changes in resource-use strategies in relation to water and sediment properties. 96 leaves were sampled in a hyper-eutrophic shallow lake in central Italy, together with environmental parameters. Results highlight the influence of water depth and sediments in modulating environmental conditions and thus leaf traits. Leaf area and fresh and dry weight increased with water depth, a relation that catches the construction costs of petioles. The negative relation found between specific petiole area and conductivity suggests a stress imposed by high nutrient availability which triggers unfavorable conditions for $N$. lutea. We demonstrated the relevance of petiole traits for a rooted macrophyte. Petiole aerenchyma or
\end{abstract}

Supplementary Information The online version contains supplementary material available at https://doi. org/10.1007/s10750-022-04803-1.

Guest editors: José L. Attayde, Renata F. Panosso, Vanessa Becker, Juliana D. Dias \& Erik Jeppesen / Advances in the Ecology of Shallow Lakes.

A. Dalla Vecchia $(\bowtie) \cdot R$. Bolpagni

Department of Chemistry, Life Sciences

and Environmental Sustainability, University of Parma,

Parma, Italy

e-mail: alice.dallavecchia@unipr.it photosynthetic extra surfaces fundamentally contribute to fit the environment, opening new questions for the functional investigation of macrophytes. Excluding petioles in the assessment of leaf traits reduces the possibility to understand the ecological/adaptive processes of nympheids. New data are urgently needed to increase the number of data and species to be analyzed.

Keywords Nympheids - Leaf economic traits · Local adaptation $\cdot$ Petioles $\cdot$ Water depth $\cdot$ Sediment properties

\section{Introduction}

Macrophytes are rapidly declining worldwide, mainly due to increased stress induced by water exploitation, habitat degradation, eutrophication, and the accumulation of alien and invasive species (O'Hare et al., 2018; Miguel-Ruano \& Sanchez-Carrillo, 2020; Bolpagni, 2021).

However, a deep and sound understanding of macrophytes functioning and dynamics along environmental gradients (e.g., trophic and depth) is still needed to prevent their decline (Azzella et al., 2017; Ghirardi et al., 2019; Angove et al., 2020).

Functional traits have been used to address a variety of ecological questions and have become more and more popular in the study of aquatic macrophytes over the last few years (Dalla Vecchia et al., 2020). 
The potential of functional traits lies in the opportunity to investigate in detail the response of single species or entire communities to a range of biotic and abiotic factors influencing their life cycle, functioning, and environment (Fu et al., 2015; Villa et al., 2017; Dalla Vecchia et al., 2020).

A common trade-off has been observed in the resource-use strategy in aquatic as well as in terrestrial plants, namely between "fast and acquisitive" and "slow and conservative" strategies, which is particularly evident in leaf traits that imply a tradeoff between fast growth on the one hand and tissue construction and protection costs on the other hand (Díaz et al., 2016; Zervas et al., 2019). To investigate the resource-use strategies of plants, a focus on traits belonging to the plant and "the leaf economics spectrum" (LES) has been proposed (Wright et al., 2004). The LES includes a complex of traits that addresses the resource allocation and investment in the photosynthetic organs, like, among others, the specific leaf area (SLA), the leaf dry matter content (LDMC), the leaf chlorophyll content, and the leaf nitrogen and phosphorus content (LNC and LPC, respectively) (Cornelissen et al., 2003; Dalle Fratte et al., 2019).

Trait variability is usually higher among species rather than within species (Siefert et al., 2015). However, accounting for intraspecific trait variability (ITV) is awakening a renewed interest among researchers in recent years (Benavides et al., 2020), because it could provide valuable information on the interactions among different plant species and between species and the environment (Violle et al., 2007). The importance of intraspecific compared to interspecific trait variability can be relatively high: Siefert et al. (2015) reported that, on average, ITV accounted for $25 \%$ of the total within community trait variance in terrestrial plant species. Neglecting to account for it could lead to only partial interpretation of the results and could mask important processes happening at the local and larger scales (Wong \& Carmona, 2021).

In this context, macrophytes have been described to show a high plasticity in traits that help them deal with the natural variability of the aquatic environment (Wells \& Pigliucci, 2000). Macrophytes are considered as highly acquisitive species, in agreement with their usually high values for SLA and high relative growth rates (Poorter et al., 2009; Grime et al., 2014). However, SLA is highly variable in macrophytes as well, and Pierce et al. (2012) show that its variability is even greater than in terrestrial plants. Moreover, among different macrophytes growth forms, they also found that nympheids presented the widest variability in leaf size and mass traits. Therefore, it will be particularly interesting to investigate the mechanisms lying behind ITV for macrophytes and nympheids in particular.

The decision whether to include petioles in leaf trait measurements clearly depends on the specific research questions of the study (Pérez-Harguindeguy et al., 2013), but in some cases including or omitting the petiole will determine significant differences in the trait values, especially for traits like SLA and LDMC (Wang et al., 2017; Wu et al., 2019). Among macrophytes growth forms, nympheids present a considerable plant height variability which will depend on water level and may grow in water up to few meters deep (Sculthorpe, 1967). To bring the leaves to the water surface, these plants need to invest in building a long petiole, which will represent a substantial proportion of the leaf mass and area (Richards et al., 2011, 2012). Besides reaching the water surface, the petioles of nympheids also work as ventilating system: oxygen flows in young leaves through the petioles and pushes out carbon dioxide and methane from older leaves, promoting colonization in deeper water (Richards et al., 2012). The scientific literature offers examples of studies that explain the relationship between water depth and macrophytes traits (i.e., Demetrio et al., 2014; Fu et al., 2014b; Li et al., 2018); however, to our knowledge, a clear evaluation of how nympheids' functional traits respond to both water and sediment qualities is still missing (but see Henriot et al., 2019).

With this study we aim at investigating the ITV of leaf traits of a representative nympheid species, the yellow water lily [Nuphar lutea (L.) Sm.] at a very local scale. Specifically, we mean to unravel the resource-use strategies of $N$. lutea in a hypereutrophic shallow lake, in relation to the resource allocation in leaf petioles and blades along local gradients of water and sediment conditions. We hypothesize that water depth has a strong influence on both petiole and blade structural traits of $N$. lutea, inducing the plant to optimize the resource allocation in blades and petioles in deeper water, and that sediment features, specifically those related to trophic level, would also determine changes in the resource-use strategy of 
this species, suggesting more stressed conditions for the plant under high trophic level.

\section{Materials and Methods}

Study site

Lake Chiusi ( $\left.43^{\circ} 03^{\prime} 22.11^{\prime \prime} \mathrm{N}, 11^{\circ} 57^{\prime} 55.79^{\prime \prime} \mathrm{E}\right)$ is a shallow hyper-eutrophic lake located in Tuscany, central Italy (Fig. 1). The lake lies at $251 \mathrm{~m}$ a.s.l. and has a surface of $3.9 \mathrm{~km}^{2}$ and an extended drainage basin of $105 \mathrm{~km}^{2}$. Fischer et al. (2016) reported a mean water depth of $3.5 \mathrm{~m}$ and a maximum depth of $5.8 \mathrm{~m}$. However, the same authors report that the lake is subjected to rapid siltation and sedimentation, so the mean depth is likely to be decreasing over the years (Lastrucci et al., 2014). The main tributary is the stream Tresa and there is one emissary, the Fosso della Ripa, which brings waters to the nearby Lake Montepulciano. Bigi \& Rustici (1984) reported a mean annual air temperature of $13.8^{\circ} \mathrm{C}$ and a mean annual rainfall of $736 \mathrm{~mm}$.

Evidence for the high trophic state of the lake is documented since the 1980s (Arrigoni \& Ricceri,
1981; Balsamo, 1990). The most recent available data from the Italian monitoring program report a mean annual concentration of Chlorophyll-a of $49 \mu \mathrm{g} \mathrm{r}^{-1}$, classifying the lake in a bad state of conservation (Cavalieri et al., 2018). High nutrients inputs come from the surrounding intensive agricultural activities; however, human pressure is homogeneously diffuse on the lake without clear patterns (SIRA ARPAT Toscana, 2005). The lake itself is exploited for recreational and professional fishery, but these activities are not intensively affecting the study area nor are they directly exploiting the macrophytes stands. Nevertheless, to avoid any possible direct human disturbance on the studied $N$. lutea plots, leaves and environmental samples were collected only from the internal sectors of stands (at least at $3 \mathrm{~m}$ from the edges of the target stands).

The site is also a protected area named "Lago di Chiusi" and in the context of the European 92/43/ EEC 'Habitats' Directive it represents a site of community importance (SCI). The lake vegetation is constituted by extended monospecific populations of $N$. lutea (Supplementary Information S1), with the sporadic presence of Nymphaea alba L. Helophytes communities are represented by Phragmites

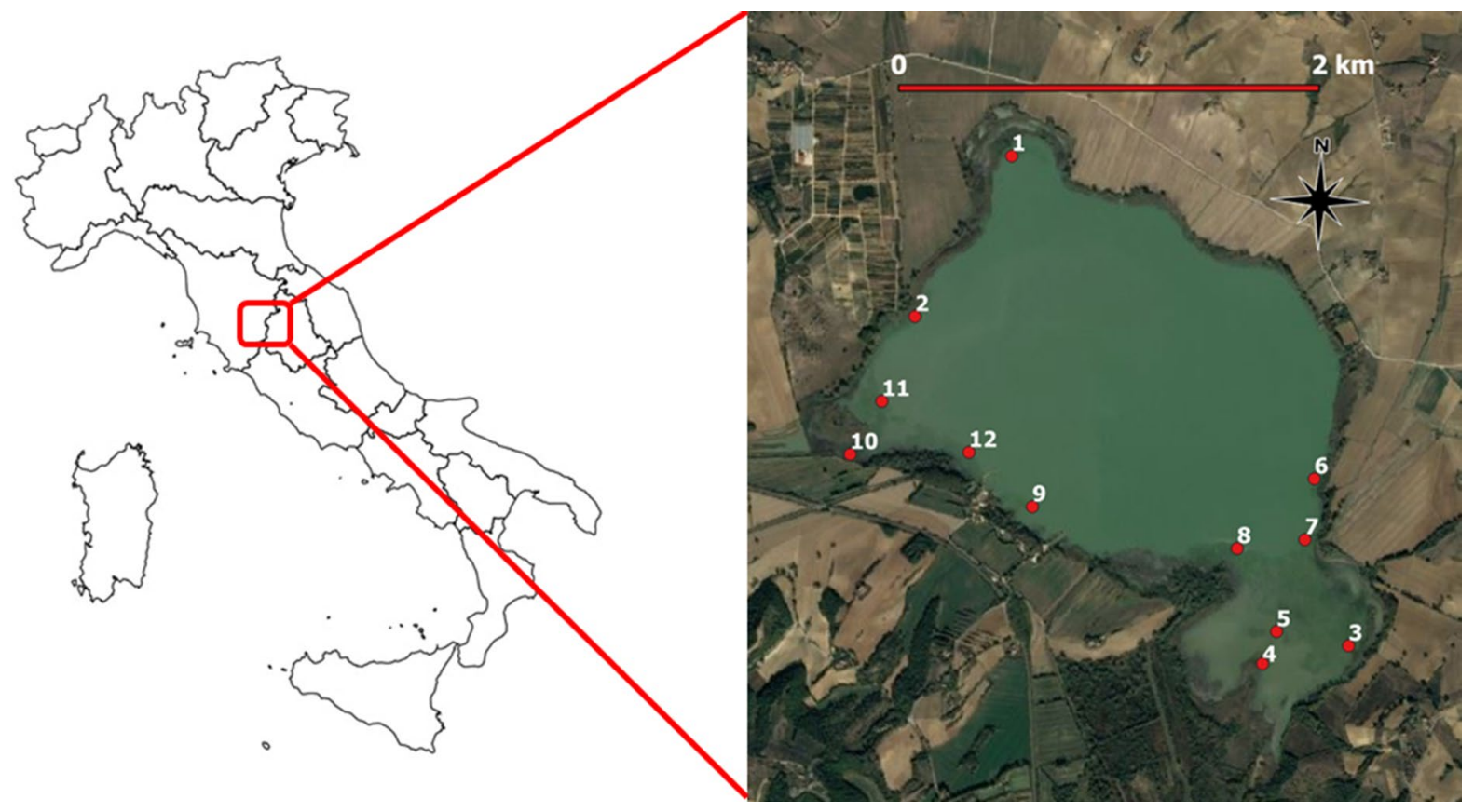

Fig. 1 Map of Lake Chiusi showing the location of sampling plots 
australis (Cav.) Trin. ex Steud., Carex elata All., and Carex riparia Curtis, while in the more riparian zone we can find examples of hygrophilous forest, like Salix alba L., Salix cinerea L., and Populus nigra L. (Lastrucci et al., 2014).

Field sampling and environmental characterization

The field sampling was carried out at the end of July 2020 and was part of the field campaigns programmed for the macroDIVERSITY project (PRIN 2017CTH94H), an Italian project of national interest that aims at integrating phylogenetic, spectral, and functional aspects of macrophytes diversity along different scales and gradients. 12 spatially independent plots of $16 \mathrm{~m}^{2}$ (monospecific $N$. lutea stands; see Fig. 1) have been chosen and characterized by sampling water, sediment, and leaves. Water temperature, dissolved oxygen (DO), conductivity (Cond), and $\mathrm{pH}$ were measured directly in the field using a multiparameter probe (YSI 556 MPS). Secchi disc and photosynthetically active radiation on the water surface and $1 \mathrm{~m}$ below the surface were also measured. Water samples were filtered in the field with GF/C glass fiber filters (Whatman), kept refrigerated in cool boxes, and frozen at $-20^{\circ} \mathrm{C}$ as soon as possible for further nutrients analyses. A sediment core was collected and the top $5 \mathrm{~cm}$ homogenized and refrigerated for further analyses. In the laboratory, soluble reactive phosphorus (SRP) and dissolved inorganic carbon (DIC) were determined within $72 \mathrm{~h}$. SRP was determined spectrophotometrically following Valderrama (1977), and DIC was determined using titration with $\mathrm{HCl} 0.1 \mathrm{~N}$ (Anderson et al., 1986). Sediment features (density, water content, porosity, organic matter content) were determined gravimetrically (Buchanan et al., 1984). Sediment total phosphorus (TP) was determined spectrophotometrically after acid extraction on a subsample of sediment ashes muffled at $450^{\circ}$ for $4 \mathrm{~h}$, following Aspila et al. (1976). At each plot, 8 undamaged, full-expanded leaves (including petioles) were collected, which presumably belonged to different individuals and represented similar life stage. Leaf samples were kept moist in wet paper towels and sealed in plastic bags and then refrigerated and processed within $72 \mathrm{~h}$.
Functional traits measures

For this study we measured a set of structural traits (Table 1)-leaf area (LA), leaf fresh weight (LFW) and dry weight (LDW), specific leaf area (SLA), and leaf dry matter content (LDMC) - for the whole leaf, including petiole, for the leaf blade only, and for the petiole only. Bio-chemical traits-phosphorus content (leafTP), chlorophyll-a (Chl-a), chlorophyll-b (Chl-b), carotenoids (Car), and the ratio between chl-a and chl-b $(\mathrm{Ca} / \mathrm{Cb})$ and between chl-a plus chl-b and Car (Chl/Car)-were measured in leaf blades only and reported on dry weight basis for TP and fresh weight basis for pigments $\left(\mu \mathrm{g} \mathrm{g}^{-1}\right)$.

The SLA is the ratio between the LA (expressed in $\mathrm{mm}^{2}$ ) and the LDW (mg), and a high SLA is considered an acquisitive trait, because it implies a lower investment in structural tissues for the photosynthetic organs, therefore a higher photosynthetic capacity per unit investment (Dalle Fratte et al., 2019). The LDMC is the ratio between LDW and LFW (g); a high LDMC, on the other hand, indicates a higher investment in structural tissues, revealing a more conservative strategy (Díaz et al., 2016). LeafTP and chlorophyll content reflect the plant photosynthetic capacity but also the tissues nutritional quality; however, they can vary quite consistently with the environmental availability of $\mathrm{N}$ and P (Wright et al., 2004; Pérez-Harguindeguy et al., 2013). To ensure traits comparability among leaves and plots, only full-expanded leaves without signs of herbivory have been collected as a proxy of similar age class. Indeed, the outermost $N$. lutea leaves (compared to the central portions of the stands) showed visible signs of herbivory that can be linked to a more prolonged emerging phase.

Water-saturated leaves were delicately washed free of debris and epiphytes, scanned for LA, and immediately weighted for LFW. They were subsequently dried at $50^{\circ} \mathrm{C}$ until constant weight and then LDW was determined. LA was determined analyzing scanned images with the software ImageJ (Rasband, 1997-2018). LeafTP was determined using the same method described for sediment TP. Pigment content was determined after 24-h extraction in $80 \%$ acetone (Wellburn, 1994). Structural traits were measured on five leaves per plot, while biochemical traits were determined on three leaves per plot, for a total of 96 leaves processed. 
Table 1 List of measured leaf traits with corresponding units of measurement and identification tags used in the text

\begin{tabular}{lll}
\hline Trait & Unit of measurement & Trait tag \\
\hline Leaf area & $\mathrm{mm}^{2}$ & LA \\
Blade area & $\mathrm{mm}^{2}$ & bladeA \\
Petiole area & $\mathrm{mm}^{2}$ & petA \\
Leaf fresh weight & $\mathrm{g}$ & LFW \\
Blade fresh weight & $\mathrm{g}$ & bladeFW \\
Petiole fresh weight & $\mathrm{g}$ & petFW \\
Leaf dry weight & $\mathrm{g}$ & LDW \\
Blade dry weight & $\mathrm{g}$ & bladeDW \\
Petiole dry weight & $\mathrm{g}^{2}$ & petDW \\
Specific leaf area & $\mathrm{mm}^{2} \mathrm{mg}^{-1}$ & SLA \\
Specific blade area & $\mathrm{mm}^{2} \mathrm{mg}^{-1}$ & bladeSLA \\
Specific petiole area & $\mathrm{mm}^{2} \mathrm{mg}^{-1}$ & petSLA \\
Leaf dry matter content & $\mathrm{mg} \mathrm{g}^{-1}$ & LDMC \\
Blade dry matter content & $\mathrm{mg} \mathrm{g}^{-1}$ & bladeDMC \\
Petiole dry matter content & $\mathrm{mg} \mathrm{g}^{-1}$ & petDMC \\
Total phosphorus content & $\mathrm{mg} \mathrm{g}^{-1}$ & leafTP \\
Chlorophyll-a content & $\mathrm{mg} \mathrm{g}^{-1}$ & Chl-a \\
Chlorophyll-b content & $\mathrm{mg} \mathrm{g}^{-1}$ & Chl-b \\
Carotenoids content & $\mathrm{mg} \mathrm{g}^{-1}$ & Car \\
Chlorophyll-a to Chlorophyll-b ratio & & Ca/Cb \\
Chlorophyll to carotenoids ratio & & Chl/Car \\
\hline & & \\
\hline
\end{tabular}

\section{Statistical analyses}

To inspect for general patterns of $N$. lutea trait responses to environmental variables, a redundancy analysis (RDA) was performed, which fits a multivariate multiple regression of response over constraining matrices (in this case trait values over environmental variables) and performs a principal component analysis on the resulting matrix of fitted values (Legendre \& Legendre, 2012). Traits mean values for each plot were used to build the response matrix. We first included water depth, $\mathrm{pH}$, conductivity, DIC, SRP, sediment porosity (por.sed), sediment organic matter content (OMC.sed), and sediment total phosphorus (TP.sed) as environmental variables, but they were then checked for collinearity and those with a Pearson correlation coefficient higher than 0.7 were omitted. We omitted water temperature and DO a priori because, in a shallow hyper-eutrophic lake, like the Lake Chiusi, they were highly variable throughout the day and plots were not sampled at the same time each day. All trait values and environmental variables included in the analysis were centered to their mean, to avoid bias related to the different scales or units of measurement of variables. A permutation test was performed after running the RDA to check for significance of the canonical axes.

To complement the RDA, we fitted linear mixed models to check for more direct relations between environmental variables and each trait and give more consistency to the analysis. This time, all the trait values from the 96 leaves measured were implemented. We use the plot number of samples as a random effect in the model. All the available environmental variables mentioned above for the RDA (omitting water temperature and DO) were employed for modeling and were standardized. We built one model for each trait, and specifically for the whole leaf trait, the blade and petiole-only traits. We proceeded with the selection of the best fitting model using the function \{dredge and selecting the model with the lowest Akaike Information Criterion (Greenacre \& Primicerio, 2014). Trait values were log transformed when patterns in the distribution of residuals were encountered.

In order to assess the contribution of the petiole and the corresponding allocation of resources, the proportion of area and fresh and dry weight of 
petioles over the whole leaf were calculated. Linear mixed models were then fitted to petiole proportion to investigate if the most important variable leading the variation of leaves structure could also influence the resource allocation between petioles and blades. Again, the plot number was included as random effect.

All statistical analyses were carried out with the software R (R Core Team, 2020), using the packages vegan (Oksanen et al., 2020), corrplot (Wei \& Simko, 2017), mgcv (Wood, 2011), lmerTest (Kuznetsova et al., 2017), usdm (Naimi et al., 2014), and MuMIn (Barton, 2020) and finally ggplot2 (Wickham, 2016), dplyr (Wickham, 2021), forcats (Wickham et al., 2021), and gridExtra (Auguie, 2017) for graphical outputs.

\section{Results}

Observations of the environmental variables and the $N$. lutea traits are available in the supplementary materials (S2 and S3). Despite the relatively small size of the studied lake $\left(3.9 \mathrm{~km}^{2}\right)$, both environmental and functional data showed a wide variability between stands. For instance, colonized water depth, conductivity, and sediment TP ranged from 0.3 to $1.9 \mathrm{~m}, 533$ to $608 \mu \mathrm{S} \mathrm{cm} \mathrm{cm}^{-1}$, and from 277 to $833 \mu \mathrm{g} \mathrm{P} \mathrm{g}^{-1}$, respectively (see S2). At the same time, LA and LDW (as representative of functional traits) ranged from 250 to $1250 \mathrm{~cm}^{2}$ and 2 to $16 \mathrm{~g}$, respectively (see $\mathrm{S} 3$ ).
Redundancy analysis

Several of the environmental variables were highly correlated $(r>0.7)$, so to run the RDA only water depth, DIC, SRP, and TP.sed were included. These variables contributed to explain $48.1 \%$ of the total variance in the data (constrained variance). Regarding the constrained components, the first two canonical axes cumulatively explained $86.0 \%$ of the variability, with RDA1 explaining 59.8\% and RDA2 25.7\% of the total constrained variance. The first RDA axis mainly described the water depth gradient, with depth decreasing with increasing values of RDA1 (RDA1 score $=-0.99$ ), but TP.sed and DIC also marginally contributed to the opposite direction of water depth (RDA1 scores $=0.49$ and 0.45 , respectively). The second RDA axis, on the other hand, was mainly related to sediment characteristics, with TP.sed having the highest RDA2 score $(-0.62)$.

The analysis showed a clear differentiation between structural and bio-chemical traits, with structural traits (LA, LFW, and LDW) increasing their values with decreasing RDA1, thus with increasing water depth, and bio-chemical traits (pigments content) increasing their values with increasing RDA2, in relation with sediment characteristics (Fig. 2). The traits that are most related to RDA1 are petA (RDA1 score $=-0.71)$, LA (RDA1 score $=-0.70)$, bladeA (RDA1 score $=-0.68)$, petSLA $(\mathrm{RDA} 1$ score $=-0.68)$, and bladeFW $($ RDA1 score $=-0.67)$, while those most related to RDA2 are Chl-a (RDA2 score $=0.54)$, Car $($ RDA2 score $=0.51)$, Chl-b $($ RDA2 score $=0.46)$, and SLA (RDA2 score $=0.45)$. However, after the permutation analysis of the model, only RDA1 resulted marginally significant $(P$-value $<0.1)$,

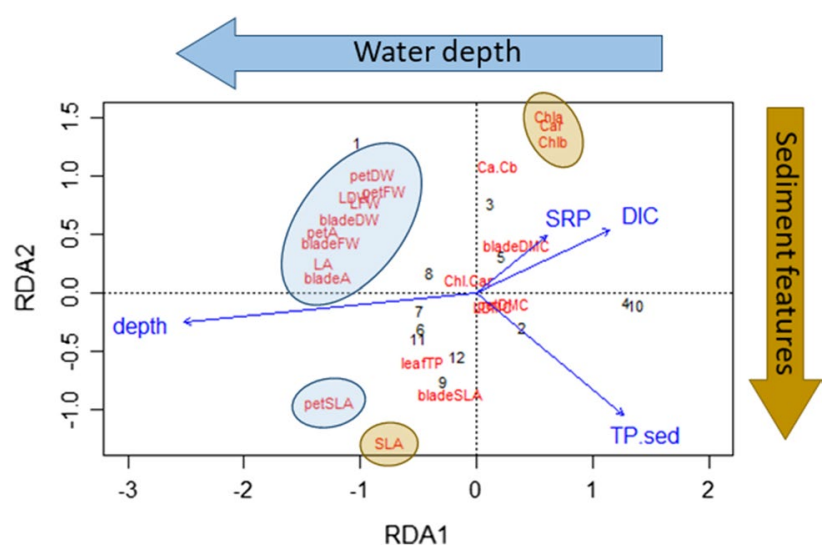

Fig. 2 Results of the RDA representing the first two canonical axes. Environmental variables are shown in blue, traits in red, and plot numbers in black. The first canonical axis indicates a water depth gradient, and traits varying along this axis are highlighted in blue. The second canonical axis is related to sediment features, and traits more related to this axis are highlighted in brown 
while the second canonical axis did not show significance.

\section{Linear mixed models}

The linear mixed models partly confirmed the results of the RDA, identifying significant correlations between environmental variables and traits. Indeed, only water depth, conductivity, and sediment TP were significantly correlated with $N$.

Table 2 Results of the linear mixed models

\begin{tabular}{|c|c|c|c|c|}
\hline Trait & Depth & Cond & OMC.sed & TP.sed \\
\hline$\overline{\mathrm{LA}}$ & $* *$ & & & \\
\hline bladeA & $* *$ & & & \\
\hline petA & $* * *$ & & & \\
\hline LFW & $P=0.0519$ & & & \\
\hline bladeFW & $* *$ & & & \\
\hline LDW & $*$ & & & \\
\hline bladeDW & $*$ & & & \\
\hline petDW & $*$ & & & \\
\hline SLA & & $P=0.0639$ & & \\
\hline bladeSLA & & & $P=0.0579$ & $*$ \\
\hline petSLA & & $* * *$ & & \\
\hline chla & & $* * *$ & & $* *$ \\
\hline chlb & & $* *$ & & \\
\hline car & & $* *$ & & \\
\hline
\end{tabular}

Only traits and environmental variables $($ Depth $=$ water column dept; Cond $=$ conductivity at $20^{\circ} \mathrm{C}$; OMC.sed $=$ sediment organic matter content; TP.sed $=$ sediment total phosphorous) that showed significant relationships are reported. Asterisks indicate the level of significance resulting from the models $(* P<0.001 ; * * P<0.01 ; * P<0.05)$. Orange colors reveal positive relations, blue colors negative ones; their intensity is related to the level of significance. $P$-values for nearly significant relationships are also reported (for the traits' tag see Table 1)

Fig. 3 Mean proportions of petiole area and fresh and dry weight on the leaf total measure $(n=60)$. Error bars represent standard deviation lutea traits (Table 2, graphical outputs available in S3). Water depth was significantly positively correlated with most of the structural traits, namely LA, bladeA, petA, bladeFW, LDW, bladeDW, and petDW. Water conductivity was significantly positively correlated with pigments content (Chl-a, Chlb, and Car) and negatively with petSLA. Sediment TP was positively correlated with bladeSLA and negatively with Chl-a. Some traits showed nearly significant relationships with environmental parameters, as was the case for LFW with depth (positive trend), or for SLA with conductivity, and bladeSLA with sediment OMC (negative trend) ( $P$-values reported in Table 2). Besides these traits, no significant relationship with environmental parameters was found also for petFW, DMC of whole leaves, blades nor petioles, leaf TP, and ratios between pigments content (Chl-a/Chl-b and Chl/Car).

\section{Petiole contribution}

Considering all samples measured for structural traits, the petiole area was on average $20.97 \%$ $( \pm 3.98 \mathrm{sd})$ of the total leaf area, 67.29\% $( \pm 5.20)$ of the total leaf fresh weight, and $43.72 \%( \pm 6.21)$ of the total leaf dry weight (Fig. 3). Area and fresh and dry weight proportions were tested against water depth, and only petiole area proportion increased significantly with increasing water depth $(P$-value $=0.0154)$, while fresh and dry weight proportions did not show significant correlations with depth (graphical outputs available in S3).

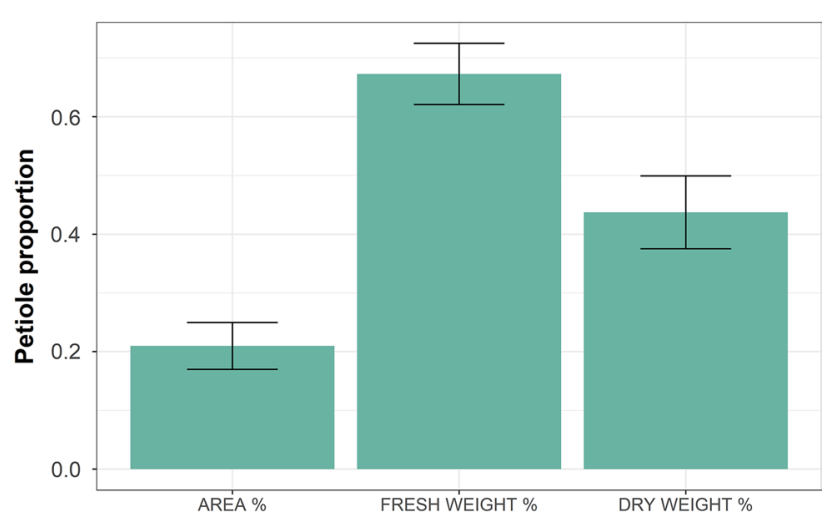




\section{Discussion}

Our findings clearly highlight how intraspecific leaf trait variability in N. lutea is modulated by the environmental conditions at the very local scale (few hundred meters). Other studies confirmed the influence of the environment on $N$. lutea performance (Henriot et al., 2019); however, to our knowledge, this is the first attempt to unravel processes happening within a single ecosystem. Indeed, Lake Chiusi was an appropriate site to test the intraspecific variability of $N$. lutea at the local scale because it is a nearly shallow stagnant system, with no stratification and negligible water mixing by the tributary and emissary streams. In this system, the influence of the sediment on the water column defines clear environmental gradients especially in the littoral zone, even in such a small water body $\left(3.9 \mathrm{~km}^{2}\right)$. The importance of water depth and substrate for the occurrence and survival of N. lutea was already evidenced in the literature (Jakubas et al., 2014).

Surprisingly, nearly half of the leaf biomass was overall allocated in the petiole (in the range 55-77\% and $29-59 \%$ for fresh and dry weight, respectively). This information confirms the non-negligible role of petioles in contributing to the leaf organ functionality, highlighting the impossibility to omit petioles from leaf traits of $N$. lutea and nympheids, more in general (Li et al., 2011). Therefore, studies including only blade traits would eventually underestimate ecological processes and adaptive responses associated to this key macrophytes group for freshwaters.

Further, the petiole area increases proportionally more than blade area along the depth gradient, although the fresh and dry weight proportions remained constant. This indicates that $N$. lutea is allocating a constant relative amount of resources to petioles, even in deeper water: a new interesting evidence about the structural and eco-physiological behavior of $N$. lutea due to the pivotal importance of petiole aerenchyma or photosynthetic extra surfaces for nympheids to fit the environment. This opens the door for additional and deeper data: widening the environments and the ecological conditions to investigate is the next needed step to strengthen our understanding of the roles of petioles in macrophyte ecology.
Environmental drivers of $N$. lutea traits variation

As postulated, among the environmental parameters evaluated, we found that water depth and conductivity were the main drivers of the observed traits variability. Water depth is crucial for N. lutea and nympheids in general, because it defines how much investment the plant needs to undertake to reach the surface with its leaves (Jin et al., 2017). Water conductivity, on the other hand, is a proxy for the trophic level of the surroundings of the sampling site (Yuwono et al., 2015; Smith et al., 2011) and in shallow waters it mainly reflects the influence of the sediment processes on the water column (Aftabuddin et al., 2017). In fact, water depth revealed to be highly negatively correlated with water conductivity (Pearson's correlation coefficient $=0.84$ ), suggesting that processes happening at the sediment-water interface clearly influence the whole water column at shallower water depths.

However, patterns resulting from the RDA have to be interpreted with caution, because of the relatively small number of $N$. lutea stands (12) included in the analysis. This is especially true for the second RDA axis that was related to pigments content of leaves. Further efforts will be needed to widen the water parameters (as $\mathrm{N}$ forms) to be included among the explanatory variables. In the present study, we focused our attention on P forms (SRP in water and TP in sediments) observing a driving role only for the sedimentary pool, whereas SRP does not seem to be directly related to the observed ITV due to strict control locally exerted by phytoplankton (with recurrent summer blooms and peaks up to $\sim 50 \mu \mathrm{g}^{-1}$, Cavalieri et al., 2018).

Nevertheless, RDA outputs were confirmed by the linear mixed models. LA increased with increasing water depth, but not only due to the increased petiole length. Indeed, we also observed an increase in the blade area. This result is informative of the investment the plant needs to face in building petioles: the construction costs need to be rewarded by a bigger photosynthetic surface. This finding is in accordance with Richards et al. (2011), who additionally observed that a single individual built fewer leaves when living in deeper water, a trend that was found also under other potential stressors for the plant, like low nutrients, $\mathrm{pH}$, and alkalinity (Klok \& van der Velde, 2017). Another evidence for the costs related to the construction of petioles lies in the significant increase of their dry weight, 
but not fresh weight, along the depth gradient, indicating the need for supporting tissue. This reinforces the importance of open spaces (e.g., aerenchyma) to boost the transport of gas to root systems for guaranteeing their functions in a hostile medium (e.g., reduced sediments). In this respect, new data are urgently necessary to explore the adaptive structural responses of petioles along environmental gradients (depth and tropic level).

In our study site, the LDMC was not correlated with any variable investigated, suggesting that the variations in fresh and dry weight were able to modulate the variability of this trait.

The SLA instead did show to be related with some environmental drivers, in this case those related to the trophic level of the system. This is in accordance with the hypothesis of Fu et al. (2014a), who did not find SLA to vary with water depth and proposed that nutrients could be more determining for aquatic plants. Considering the SLA an acquisitive trait, we can expect that a healthy plant can afford to have a higher SLA and keep a higher growth rate (Poorter et al., 2009). The negative relationship observed between SLA and variables related to the trophic level of the system (conductivity and sediment OMC) suggests that the plant is probably facing a stressful condition and is switching to a more conservative strategy. This relationship was only a trend for whole leaf and blade SLA, but it was clear for the petiole SLA. A high trophic level acts as fertilizer and promotes plant growth (Lehmann et al., 1997; Bornette $\&$ Puijalon, 2011), which in our case was confirmed by the increase in the blade SLA with increasing sediment TP or in the higher pigments content at higher conductivity values. Henriot et al. (2019) also found positive relationships between sediment phosphorus and growth and reproduction traits in $N$. lutea. But this situation can also trigger processes with negative impacts for plant growth: a high productivity in the system induces high respiration rates from the bacterial community, resulting in anoxia and consequent possible accumulation of toxic compounds (Muri \& Wakeham, 2006; Wu et al., 2013; Henriot et al., 2019).

\section{Conclusion}

A very limited number of trait studies have focused their attention on petioles so far, especially for macrophytes, and international protocols for traits collection do not pay enough attention to aquatic plant's morphological peculiarities in defining, for example, whether petioles should be included or omitted in the trait analyses. Our results report that omitting information on petioles in nympheids would lead to a very partial understanding of plant responses to local environmental conditions. Petioles not only have a support and transport function but represent "functional-morphological hot-spots" capable of contributing significantly to the performance of individuals. The present results suggest the need to deepen the functional roles of petioles opening new research lines to better capture the biotic-abiotic interactions and dynamics in freshwaters. At the same time, rather than to find general laws of traits variation in the environmental space, with this study we also aimed to highlight that there are processes happening even within the lake scale (few hundred meters) that can influence the plant performance in multiple ways. Our dataset was limited in the number of samples, so a future integration with a higher number of observations in different sites will allow to deepen the trends observed in traits variation in this study for $N$. lutea.

Acknowledgements We would thank all the team of the macroDIVERSITY project (Paolo Villa, from CNR-IREA; Maria Beatrice Castellani, Andrea Coppi, and Lorenzo Lastrucci from UNIFI and the Italian Central Herbarium) for the valuable support during the field activities. We are also grateful to Davide Taglialatela for his help in laboratory activities. Finally, we would like to thank the two anonymous reviewers for their precious comments and suggestions which helped to improve the final version of the present paper.

Author contributions All authors contributed to the study conception and design, material preparation, and data collection. Laboratory analyses were performed by ADV. The first draft of the manuscript was written by ADV and RB commented on previous versions of the manuscript. All authors read and approved the final manuscript.

Funding This work has been supported by the project "macroDIVERSITY," funded by the Ministry of Education, University and Research, PRIN 2017 [Grant 2017CTH94H]. ADV has benefited from the equipment and framework of the COMPHUB Initiative, funded by the 'Departments of Excellence' program of the Italian Ministry for Education, University and Research (MIUR, 2018-2022).

Data availability The data that support the findings of this study are available from the corresponding author, upon reasonable request. 
Code availability Not applicable.

\section{Declarations}

Conflict of interest The author declares that they have no conflict of interest.

Open Access This article is licensed under a Creative Commons Attribution 4.0 International License, which permits use, sharing, adaptation, distribution and reproduction in any medium or format, as long as you give appropriate credit to the original author(s) and the source, provide a link to the Creative Commons licence, and indicate if changes were made. The images or other third party material in this article are included in the article's Creative Commons licence, unless indicated otherwise in a credit line to the material. If material is not included in the article's Creative Commons licence and your intended use is not permitted by statutory regulation or exceeds the permitted use, you will need to obtain permission directly from the copyright holder. To view a copy of this licence, visit http://creativecommons.org/licenses/by/4.0/.

\section{References}

Aftabuddin, M., M. A. Hassan, A. K. Das, B. C. Jha \& A. P. Sharma, 2017. Effect of river connectivity on hydrochemistry, sediment enzyme activity and biotic communities of wetlands. Aquatic Ecosystem Health and Management 20: 140-150.

Anderson, L. G., P. O. J. Hall, A. Iverfeldt, M. M. R. Van Der Loeff, B. Sundby \& S. F. G. Westerlund, 1986. Benthic respiration measured by total carbonate production. Limnology and Oceanography 31: 319-329.

Angove, C., A. Norkko \& C. Gustafsson, 2020. The fight to capture light: functional diversity is related to aquatic plant community productivity likely by enhancing light capture. Frontiers in Marine Science 7: 1-13.

Arrigoni, P. V. \& C. Ricceri, 1981. La vegetazione dei laghi di Chiusi e di Montepulciano (Siena). (The vegetation of the lakes of Chiusi and Montepulciano (Prov. of Siena).). Atti Soc. Tosc. Sci. Nat. Mem. b. 88: 285-299.

Aspila, K. I., H. Agemian \& A. S. Y. Chau, 1976. A semiautomated method for the determination of inorganic, organic and total phosphate in sediments. Analyst 101: 187-197.

Auguie, B., 2017. gridExtra: Miscellaneous Functions for "Grid" Graphics. R package version 2.3.

Azzella, M. M., M. Bresciani, D. Nizzoli \& R. Bolpagni, 2017. Aquatic vegetation in deep lakes: macrophyte co-occurrence patterns and environmental determinants. Journal of Limnology 76: 97-108.

Balsamo, M., 1990. Gastrotrichs from Lakes Bolsena, Chiusi and Montepulciano (central Italy), with the description of four new species. Italian Journal of Zoology 57: 165-178.

Barton, K., 2020. MuMIn: Multi-Model Inference. R package version 1.43.17. https://CRAN.R-project.org/package= MuMIn

Benavides, R., B. Carvalho, C. C. Bastias, D. L. Antonio, M. Stephen, C. Alan, A. Albet, R. Alía, O. Ambrosio, F. Aravanopoulos, F. Auñón, C. Avanzi, E. V. Avramidou, F.
Bagnoli, E. Ballesteros, E. Barbas, C. Bastien, F. Bernier, H. Bignalet, D. Bouic, W. Brunetto, J. Buchovska, A. M. C. Nicolas, C. José, M. C. Marianne, E. Cremer, D. Danusevičius, B. Dauphin, F. Del, J. D. Bernard, D. Rémi, D. A. Farsakoglou, A. Fera, P. Fonti, I. Ganopoulos, J. M. García, A. Hurel, B. Issehuth, F. Jean \& V. Jorge, 2020. The GenTree leaf collection: inter- and intraspecific leaf variation in seven forest tree species in Europe. Global Ecology and Biogeography 30: 590-597.

Bigi, L. \& L. Rustici, 1984. Regime idrico dei suoli e tipi climatici in Toscana. Dipartimento Agricoltura e Foreste, Regione Toscana.

Bolpagni, R., 2021. Towards global dominance of invasive alien plants in freshwater ecosystems: the dawn of the Exocene? Hydrobiologia 848: 2259-2279.

Bornette, G. \& S. Puijalon, 2011. Response of aquatic plants to abiotic factors: a review. Aquatic Sciences 73: 1-14.

Buchanan, J. B., N. A. Holme \& A. D. McIntyre, 1984. Methods for the study of marine benthos. IBP Hand Book 16: 41-65.

Cavalieri, S., G. Spinelli \& C. Bondi, 2018. Monitoraggio ambientale corpi idrici superficiali: fiumi, laghi, acque di transizione. SIRA ARPAT.

Cornelissen, J. H. C., S. Lavorel, E. Garnier, S. Díaz, N. Buchmann, D. E. Gurvich, P. B. Reich, H. Ter Steege, H. D. Morgan, M. G. A. Van Der Heijden, J. G. Pausas \& H. Poorter, 2003. A handbook of protocols for standardised and easy measurement of plant functional traits worldwide. Australian Journal of Botany 51: 335-380.

Dalla Vecchia, A., P. Villa \& R. Bolpagni, 2020. Functional traits in macrophyte studies: current trends and future research agenda. Aquatic Botany 167: 103290.

Dalle Fratte, M., G. Brusa, S. Pierce, M. Zanzottera \& B. E. L. Cerabolini, 2019. Plant trait variation along environmental indicators to infer global change impacts. Flora: Morphology 254: 113-121.

Demetrio, G., M. Barbosa \& F. Coelho, 2014. Water leveldependent morphological plasticity in Sagittaria montevidensis Cham. and Schl. (Alismataceae). Brazilian Journal of Biology 74: S199-S206.

Díaz, S., E. Garnier, S. Lavorel, H. Poorter, P. Jaureguiberry, W. K. Cornwell, J. M. Craine, D. E. Gurvich, C. Urcelay, E. J. Veneklaas, P. B. Reich, L. Poorter, I. J. Wright, P. Ray, L. Enrico, J. G. Pausas, A. C. De Vos, N. Buchmann, G. Funes, F. Quétier, J. G. Hodgson, K. Thompson, H. D. Morgan, H. Steege, M. G. A. Van Der Heijden, L. Sack, B. Blonder, P. Poschlod, M. V. Vaieretti, G. Conti, A. C. Staver, S. Aquino \& J. H. C. Cornelissen, 2016. Corrigendum: New handbook for standardised measurement of plant functional traits worldwide (Australian Journal of Botany (2013) 61:167-234). Australian Journal of Botany 64: 715-716.

Fischer, E. K., L. Paglialonga, E. Czech \& M. Tamminga, 2016. Microplastic pollution in lakes and lake shoreline sediments - a case study on Lake Bolsena and Lake Chiusi (central Italy). Environmental Pollution 213: 648-657.

Fu, H., J. Zhong, G. Yuan, L. Ni, P. Xie \& T. Cao, 2014a. Functional traits composition predict macrophytes community productivity along a water depth gradient in a freshwater lake. Ecology and Evolution 4: 1516-1523. 
Fu, H., J. Zhong, G. Yuan, P. Xie, L. Guo, X. Zhang, J. Xu, Z. Li, W. Li, M. Zhang, T. Cao \& L. Ni, 2014b. Traitbased community assembly of aquatic macrophytes along a water depth gradient in a freshwater lake. Freshwater Biology 59: 2462-2471.

Fu, H., J. Zhong, G. Yuan, C. Guo, Q. Lou, W. Zhang, J. Xu, L. Ni, P. Xie \& T. Cao, 2015. Predicting changes in macrophyte community structure from functional traits in a freshwater lake: a test of maximum entropy model. PLoS ONE 10: 1-11.

Ghirardi, N., R. Bolpagni, M. Bresciani, G. Valerio, M. Pilotti \& C. Giardino, 2019. Spatiotemporal dynamics of submerged aquatic vegetation in a deep lake from sentinel-2 data. Water 11: 563.

Greenacre, M. \& R. Primicerio, 2014. Multivariate analysis of ecological data. Fundacion BBVA.

Grime, J. P., J. G. Hodgson \& R. Hunt, 2014. Comparative plant ecology: a functional approach to common British species, Springer:

Henriot, C. P., Q. Cuenot, L. H. Levrey, C. Loup, L. Chiarello, H. Masclaux \& G. Bornette, 2019. Relationships between key functional traits of the waterlily Nuphar lutea and wetland nutrient content. PeerJ 2019: 1-27.

Jakubas, E., M. Gąbka \& T. Joniak, 2014. Morphological forms of two macrophytes (yellow water-lily and arrowhead) along velocity gradient. Biologia (Poland) 69: 840-846.

Jin, Q., Y. Wang, X. Li, S. Wu, Y. Wang, J. Luo, N. Mattson \& Y. Xu, 2017. Interactions between ethylene, gibberellin and abscisic acid in regulating submergence induced petiole elongation in Nelumbo nucifera. Aquatic Botany 137: 9-15.

Klok, P. F. \& G. van der Velde, 2017. Plant traits and environment: floating leaf blade production and turnover of waterlilies. PeerJ 5: e3212.

Kuznetsova, A., P. B. Brockhoff \& R. H. B. Christensen, 2017. lmerTest package: tests in linear mixed effects models. Journal of Statistical Software 82: 1-26.

Lastrucci, L., G. Bonari, C. Angiolini, F. Casini, T. Giallonardo, D. Gigante, M. Landi, F. Landucci, R. Venanzoni \& D. Viciani, 2014. Vegetation of Lakes Chiusi and Montepulciano (Siena, central Italy): updated knowledge and new discoveries. Plant Sociology 51: 29-55.

Legendre, P. \& L. Legendre, 2012. Numerical Ecology, Elsevier, New York:

Lehmann, A., E. Castella \& J. B. Lachavanne, 1997. Morphological traits and spatial heterogeneity of aquatic plants along sediment and depth gradients, Lake Geneva, Switzerland. Aquatic Botany 55: 281-299.

Li, Z., D. Yu \& J. Xu, 2011. Adaptation to water level variation: responses of a floating-leaved macrophyte Nymphoides peltata to terrestrial habitats. Annales De Limnologie - International Journal of Limnology 47: 97-102.

Li, Y., X. B. Yu, Y. Liu, G. S. Zhang, Q. J. Zhang \& H. L. Duan, 2018. Response of wetland plant functional traits to hydrological processes: a review. Chinese Journal of Ecology 37: 952-959.

Miguel-Ruano, M. \& S. Sanchez-Carrillo, 2020. El declive de la vegetación acuática en los humedales como respuesta a la degradación ambiental: el caso de la masiega (Cladium mariscus) en Las Tablas de Daimiel y su restauración potencial. Revista Ecosistemas 29: 1963.

Muri, G. \& S. G. Wakeham, 2006. Organic matter and lipids in sediments of Lake Bled (NW Slovenia): source and effect of anoxic and oxic depositional regimes. Organic Geochemistry Pergamon 37: 1664-1679.

Naimi, B., N. A. S. Hamm, T. A. Groen, A. K. Skidmore \& A. G. Toxopeus, 2014. Where is positional uncertainty a problem for species distribution modelling. Ecography 37: 191-203.

O’Hare, M. T., F. C. Aguiar, T. Asaeda, E. S. Bakker, P. A. Chambers, J. S. Clayton, A. Elger, T. M. Ferreira, E. M. Gross, I. D. M. Gunn, A. M. Gurnell, S. Hellsten, D. E. Hofstra, W. Li, S. Mohr, S. Puijalon, K. Szoszkiewicz, N. J. Willby \& K. A. Wood, 2018. Plants in aquatic ecosystems: current trends and future directions. Hydrobiologia 812: $1-11$.

Oksanen J., F. G. Blanchet, M. Friendly, R. Kindt, P. Legendre, D. McGlinn, P. R. Minchin, R. B. O'Hara, G. L. Simpson, P. Solymos, M. H. H. Stevens, E. Szoecs \& H. Wagner, 2020. R package "vegan": Community Ecology Package. $\mathrm{R}$ package version $2.5-7$.

Pérez-Harguindeguy, N., S. Díaz, E. Garnier, S. Lavorel, H. Poorter, P. Jaureguiberry, M. S. Bret-Harte, W. K. Cornwell, J. M. Craine, D. E. Gurvich, C. Urcelay, E. J. Veneklaas, P. B. Reich, L. Poorter, I. J. Wright, P. Ray, L. Enrico, J. G. Pausas, A. C. De Vos, N. Buchmann, G. Funes, F. Quétier, J. G. Hodgson, K. Thompson, H. D. Morgan, H. Ter Steege, M. G. A. Van Der Heijden, L. Sack, B. Blonder, P. Poschlod, M. V. Vaieretti, G. Conti, A. C. Staver, S. Aquino \& J. H. C. Cornelissen, 2013. New handbook for standardised measurement of plant functional traits worldwide. Australian Journal of Botany CSIRO 61: 167-234.

Pierce, S., G. Brusa, M. Sartori \& B. E. L. Cerabolini, 2012. Combined use of leaf size and economics traits allows direct comparison of hydrophyte and terrestrial herbaceous adaptive strategies. Annals of Botany 109: 1047-1053.

Poorter, H., Ü. Niinemets, L. Poorter, I. J. Wright \& R. Villar, 2009. Causes and consequences of variation in leaf mass per area (LMA): a meta-analysis. New Phytologist 182: $565-588$.

R Core Team, 2020. R: A language and environment for statistical computing. R Foundation for Statistical Computing, Vienna, Austria. https://www.R-project.org/

Rasband, W.S., 1997-2018. ImageJ, U. S. National Institutes of Health, Bethesda, Maryland, USA, https://imagej.nih.gov/ ij/.

Richards, J. H., T. G. Troxler, D. W. Lee \& M. S. Zimmerman, 2011. Experimental determination of effects of water depth on Nymphaea odorata growth, morphology and biomass allocation. Aquatic Botany 95: 9-16.

Richards, J. H., D. N. Kuhn \& K. Bishop, 2012. Interrelationships of petiolar air canal architecture, water depth, and convective air flow in Nymphaea odorata (Nymphaeaceae). American Journal of Botany 99: 1903-1909.

Sculthorpe, C. D., 1967. The Biology of Aquatic Vascular Plants, Edward Arnold, London:

Siefert, A., C. Violle, L. Chalmandrier, C. H. Albert, A. Taudiere, A. Fajardo, L. W. Aarssen, C. Baraloto, M. B. 
Carlucci, M. V. Cianciaruso, V. L. Dantas, F. de Bello, L. D. S. Duarte, C. R. Fonseca, G. T. Freschet, S. Gaucherand, N. Gross, K. Hikosaka, B. Jackson, V. Jung, C. Kamiyama, M. Katabuchi, S. W. Kembel, E. Kichenin, N. J. B. Kraft, A. Lagerström, Y. Le Bagousse-Pinguet, Y. Li, N. Mason, J. Messier, T. Nakashizuka, J. M. Overton, D. A. Peltzer, I. M. Pérez-Ramos, V. D. Pillar, H. C. Prentice, S. Richardson, T. Sasaki, B. S. Schamp, C. Schöb, B. Shipley, M. Sundqvist, M. T. Sykes, M. Vandewalle \& D. A. Wardle, 2015. A global meta-analysis of the relative extent of intraspecific trait variation in plant communities. Ecology Letters 18: 1406-1419.

SIRA ARPAT Toscana, 2005. http://sira.arpat.toscana.it/ sira/MedWet/MDW_IT51309202.htm (last accessed 15/03/2021)

Smith, L., M. C. Watzin \& G. Druschel, 2011. Relating sediment phosphorus mobility to seasonal and diel redox fluctuations at the sediment-water interface in a eutrophic freshwater lake. Limnology and Oceanography 56: 2251-2264.

Valderrama, J. C., 1977. Methods used by the hydrographica department of the national board of fisheries. Goteborg, Sweden

Villa, P., M. Pinardi, V. R. Toth, P. D. Hunter, R. Bolpagni \& M. Bresciani, 2017. Remote sensing of macrophyte morphological traits: implications for the management of shallow lakes. Journal of Limnology 76: 109-126.

Violle, C., M.-L. Navas, D. Vile, E. Kazakou, C. Fortunel, I. Hummel \& E. Garnier, 2007. Let the concept of trait be functional! Oikos 116: 882-892.

Wang, C., J. Zhou, H. Xiao, J. Liu \& L. Wang, 2017. Variations in leaf functional traits among plant species grouped by growth and leaf types in Zhenjiang, China. Journal of Forestry Research 28: 241-248.

Wei, T. \& V. Simko, 2017. R package "corrplot": visualization of a Correlation Matrix (Version 0.84).

Wellburn, A. R., 1994. The spectral determination of chlorophylls A and B, as well as Total caroteinds, using various solvents with Spectrophotometers of different resolution. Journal of Plant Physiology 144: 307-313.

Wells, C. L. \& M. Pigliucci, 2000. Adaptive phenotypic plasticity: the case of heterophylly in aquatic plants. Perspectives in Plant Ecology, Evolution and Systematics 3: 1-18.

Wickham, H., 2016. R package "ggplot2": Elegant Graphics for Data Analysis, Springer, New York:

Wickham, H., R. François, L. Henry, \& K. Müller, 2021. R package "dplyr": A Grammar of Data Manipulation. R package version 1.0.7.
Wickham, H., 2021. R package "forcats": Tools for Working with Categorical Variables (Factors). R package version 0.5 .1 .

Wong, M. K. L. \& C. P. Carmona, 2021. Including intraspecific trait variability to avoid distortion of functional diversity and ecological inference: lessons from natural assemblages. Methods in Ecology and Evolution 12: 946-957.

Wood, S. N., 2011. Fast stable restricted maximum likelihood and marginal likelihood estimation of semiparametric generalized linear models. Journal of the Royal Statistical Society (b) 73: 3-36.

Wright, I. J., P. B. Reich, M. Westoby, D. D. Ackerly, Z. Baruch, F. Bongers, J. Cavender-Bares, T. Chapin, J. H. C. Cornellssen, M. Diemer, J. Flexas, E. Garnier, P. K. Groom, J. Gulias, K. Hikosaka, B. B. Lamont, T. Lee, W. Lee, C. Lusk, J. J. Midgley, M. L. Navas, Ü. Niinemets, J. Oleksyn, H. Osada, H. Poorter, P. Pool, L. Prior, V. I. Pyankov, C. Roumet, S. C. Thomas, M. G. Tjoelker, E. J. Veneklaas \& R. Villar, 2004. The worldwide leaf economics spectrum. Nature 428: 821-827.

Wu, J., N. Cui \& S. Cheng, 2013. Effects of sediment anoxia on growth and root respiratory metabolism of Iris pseudacorus: implications for vegetation restoration of eutrophic waters in China. Ecological Engineering 53: 194-199.

Wu, B., J. Liu, K. Jiang, J. Zhou \& C. Wang, 2019. Differences in leaf functional traits between simple and compound leaves of Canavalia maritime. Polish Journal of Environmental Studies 28: 1425-1432.

Yuwono, T., W. B. Pramono, I. Ardi, L. Hakim \& M. Ismail, 2015. Design of the remote sensing circuit for water conductivity. International Conference on Space Science and Communication, IconSpace: 84-88.

Zervas, D., V. Tsiaoussi, A. S. Kallimanis, P. Dimopoulos \& I. Tsiripidis, 2019. Exploring the relationships between aquatic macrophyte functional traits and anthropogenic pressures in freshwater lakes. Acta Oecologica 99: 103443 .

Publisher's Note Springer Nature remains neutral with regard to jurisdictional claims in published maps and institutional affiliations. 